\title{
The Role of Competence in Improving Employee Performance Village-Owned Enterprises (BUMDES) in Kulon Progo Regency
}

\author{
Fitri Rahmawati ${ }^{1}$ Dedi Runanto ${ }^{2}$ \\ Faculty of Economic, Management Study Program, \\ Muhammadiyah University of Purworejo \\ fitrirahmawati@umpwr.ac.id
}

\begin{abstract}
Village-owned enterprises (Bumdes) are village businesses managed by the Village Government that aim to meet the needs of village communities and raise the superior potential of a village. The village is one of the potential places to develop the village economy. The existence of Village-Owned Enterprises (Bumdes) in the era of the industrial revolution 4.0 is a solution for developing village economic activities through structured management by utilizing reliable and competent human resources. Potential competencies as well as reality competencies have an important role for employees in improving performance to carry out the operational activities of Village-Owned Enterprises, as an effort to drive the leading rural local sector
\end{abstract}

This study aims to determine the effect of potential competence and reality competence on the performance of employees of Village-Owned Enterprises (Bumdes) in Kulon Progo Regency. The research population was all employees of Bumdes in Kulon Progo Regency, amounting to 71 people. The sampling technique used a saturated sample method of 71 people. Data were collected using a questionnaire consisting of five answer choices and also interviews. The questionnaire was tested to meet the validity and reliability requirements. This test was carried out with the SPSS 19.0 program.

The results of the Multiple Linear Regression analysis show that potential competencies do not have a significant effect on the performance of employees of VillageOwned Enterprises, even though the nature of the relationship is positive. However, the competence that is believed to have an effect on improving the performance of employees is reality competence. Reality competencies related to knowledge, willingness, and technical expertise in accordance with the field of work both in the form of work experience and talent play a role in improving the quality of employee performance. Therefore, the Bumdes is expected to be able to strengthen the reality competencies of employees by providing additional knowledge, strengthening the willingness to learn and improving employee skills. Efforts to strengthen the reality competence of employees are expected to make it easier for employees and also Bumdes to identify problems and find creative and quality solutions for the progress of Bumdes in the era of industrial revolution 4.0 which is increasingly competitive.

Keywords: Potential Competence, Reality Competence and Employee Performance

\section{INTRODUCTION}

The phenomenon occurred, in the Industrial Revolution 4.0 not just occur in the new technology, but to new ideas. Disruption of the Industrial Revolution 4.0 targeting the inefficient industries making it difficult for HR to develop their potential. Enormous challenges faced by the village in finding a strategy to manage its human resources in order to remain in the best performance of the work is an effort to increase employee performance through a strategy of improving the competence of the performance. According Wibowo (2017: 272) competency is a fundamental characteristic in every individual associated with the criteria referenced against superior performance or effective in a job.

Kulon Progo Regency continues to carry out business development in an effort to alleviate poverty and compete in the era of the Industrial Revolution 4.0. In 2008 the Kulon Progo regency formed a Micro Finance Institution (MFI) located in the respective villages. The phenomenon of the background for the establishment of MFI is the savings and loan business that damning of "creditors" in the community and serves as the owner is the village administration to increase revenue villages. Public interest against the existence of MFI is showed a significant response. It can be seen from the response of the community in financing micro initially often in cooperation with the moneylenders and then switch to the MFI (www.kulonprogokab.go.id, 2019).

In 2013, the existence of MFIs that did not have a legal entity became an obstacle in improving the performance of both organizational and individual performance. Then, based on Law No. 32 of 2004 and Law No. 22/1999 and Regulation 71 of 2005 on the village, Regulation 39 of 2010 on BUMDes and Perbub 38 in 2012, then formed village-owned enterprises with MFI as embryos business unit that serves the operational running of business activities to manage the business so as to increase revenue villages. Therefore it is necessary human resources in creative and innovative so as to become a pillar of the economic development of the village that serves as the social institutions (social instution) and commercial (commercial instution).

Transfer of Microfinance Institutions into BUMDes there are obstacles among which Microfinance Institutions belonging unhealthy in running its business operations. Low profits paid to the Village Government, the lack of improvement of the quality of employee performance BUMDes, low competence and communication in developing as well as the partners of the data assessment Secretariat for Economic Kulon Progo Regency in 2016 and 2017 showed that $51.7 \%$ or 45 BUMDes of 88 BUMDes that the 22 BUMDes classified elected healthy. The focus of this research is the study of "BUMDes Employee Performance Improvement Strategies through potential competence and reality competence in Kulon Progo Regency”. 


\section{PROBLEMIDENTIFICATION}

Low employee competence due to a phenomenon governance changes in Microfinance Institutions transformed into a village-owned enterprises.

\section{PROBLEM FORMULATION}

The research problem is formulated as follows:

1. Does the role of potential competence affect the performance of employees of Village-Owned Enterprises (BUMDes) in Kulon Progo Regency?

2. Does the role of reality competence affect the performance of employees of Village-Owned Enterprises (BUMDes) in Kulon Progo Regency?

\section{STUDY THEORY AND FRAMEWORK FOR THOUGHT}

\section{Study Theory}

\section{a. Employee Performance}

Performance by Mangkunagara (2007: 9), was the work or performance to be achieved by a person of the activities that have been carried out. This definition implies that to achieve high levels of performance, an employee must do a good job (motivation), must be able to do the job effectively (ability) and must have the material, resources, equipment and information to do the job (environment). According to Edison et al. (2018:

203) performance is the result of a process that refers and measured over a certain period of time based on predetermined terms or agreements.

b. Competence

According to Spencer and Spencer (1993: 9) there are basically two forms of potential, namely: physical potential, capabilities and can be developed or enhanced if trained properly and mental potential (psychic), which forms the strength mentally-owned and allows for improved or developed if studied and trained. Spencer and Spencer (1993: 10) state that the potential capability is something inherent in the personality of someone who is always there and can predict behavior and its performance in general in various job situations and tasks. According to Spencer and Spencer (1993: 9) competence reality, including the ability to knowledge and skills is the ability to do a job with skill. The level of knowledge (knowledge level) contains the ability to recognize and remember the terminology, definitions, facts, ideas, patterns, sequences, methodologies, basic principles, and etc.

\section{Conceptual Framework}

The framework of this study systematically can be seen in the following chart:

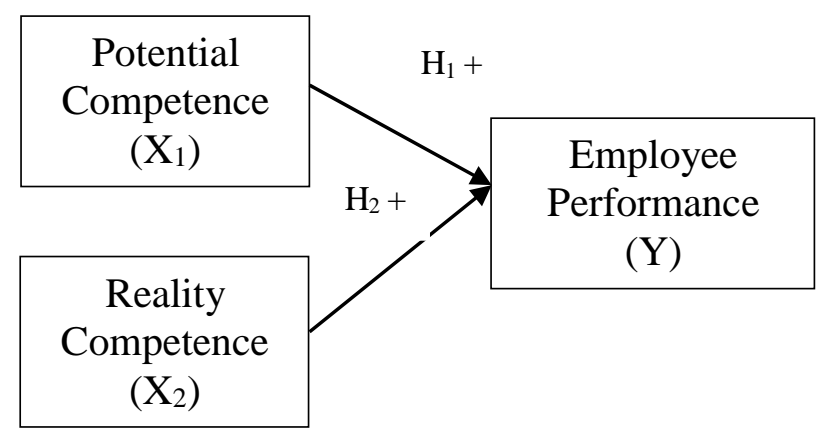

Picture 1

Framework Conceptual

Description :

: Influence of independent variables on the dependent variable partially.

\section{HYPOTHESIS}

1. Analysis of Potential Competence the Employee Performance

Spencer and Spencer (1993: 9) attitude (attitude) upholding the ethics of the organization, and have a positive attitude in the act, which is part of the competence of individual potential. This attitude can not be separated from the employee's duties in performing work properly which is an important element influence on the image of the organization. The acceptance of the first hypothesis in this study is in accordance with the results of previous research conducted by Jonnius (2015), proving that potential competence does not affect the performance achievement of employees of Village-Owned Enterprises.

H1: Potential competence does not affect employee performance

2. Analysis of reality ability or reality competence on performance

According to Spencer and Spencer (1993: 9) competence reality, including the ability to knowledge and skills is the ability to do a job with skill. The level of knowledge (knowledge level) contains the ability to recognize and remember the terminology, definitions, facts, ideas, patterns, sequences, methodologies, basic principles, and etc. Jonius Research (2014), Swandari et al. (2017) and Musafir (2007) competence reality show positive and significant impact on performance.

H2: Reality competence affects employee performance at BUMDes in Kulon Progo Regency.

\section{RESEARCH METHOD}

\section{Variable Operational Definition}

\section{a. Performance (Y)}

According to Edison et al. (2018: 203) performance is the result of a process that refers to and measured over a certain period of time under the provisions or agreements that has been designated. Performance indicators according to Edison et al. (2018: 203), namely: 1) Target, 2) Quality, 3) Time of completion, 4) Obey the principle. 


\section{b. Potential competence $(\mathrm{X} 1)$}

Spencer and Spencer (1993: 10) state that potential ability is something inherent in a person's personality which is present and predict general behavior and performance in various situations and job tasks. Potential competance indicators according to Spencer and Spencer (1993: 10), as follows: Attitude (attitude), upholding the ethics of the organization, and have a positive attitude in the act. This attitude cannot be separated from the employee's job in carrying out the job properly which is an important element that affects the image of theorganization.

\section{c. Reality competence (X2)}

According to Spencer and Spencer (1993: 9) reality competence, including the ability to knowledge and skills is the ability to do a job with skill. The level of knowledge (knowledge level) contains the ability to recognize and remember the terminology, definitions, facts, ideas, patterns, sequences, methodologies, basic principles, and etc. Indicators of potential competance according to Spencer and Spencer (1993: 10), as follows: 1) Knowledge (knowledge), has the knowledge gained from a formal learning and training related to the field of work they handle, 2) Expertise ( skills), has the expertise to handle the work and able to handle it in detail. Thus, employees have an ability (ability) to solve the problem and solve it quickly and efficiently.

\section{Testing Instrument Research}

\section{a. Validity test}

A questionnaire considered valid ifthe questions in the questionnaire were able to reveal something that will be measured by the questionnaire (Ghozali, 2011: 52). Measuring validity can be done by performing the correlation between the scores of the questions with a total score of constructs or variables. Measure the validity of the questionnaire given to respondents, is done by comparing the value of Cronbach Alpha column corelated Item-total, ie by comparing corelated ItemTotal Correlation with the calculated rtabel $(\mathrm{df})=\mathrm{n}-2, \mathrm{n}$ is the value of the number of samples. If, rcount $>$ rtable and is positive then the question or indicator item is declared valid, whereas if rcount <rtable then the question item or indicator is declared invalid (Ghozali, 2011: 53).

Based on the results of the instrument validity test, using the Corrected Item-Total Correlation shows that all indicators of potential competence (X1), reality competence (X2), performance $(\mathrm{Y})$ have a correlation coefficient above 0.3610 (rtable, with $\mathrm{n}=30, \mathrm{df}=28$ ) and all of them are positive, so that it can be concluded that all indicators tested statement is valid, it means that every item statement (instrument) in the questionnaire to measure the research variables appropriately.
Table 1

Validity Test Result

\begin{tabular}{|c|c|c|c|}
\hline Variable & $\begin{array}{l}\text { Statement } \\
\text { Items }\end{array}$ & $\begin{array}{c}\text { Corrected } \\
\text { Item-Total } \\
\text { Correlation }\end{array}$ & $\begin{array}{c}\mathbf{r} \\
\text { Tabel }\end{array}$ \\
\hline \multirow{7}{*}{$\begin{array}{c}\text { Potential } \\
\text { Competence } \\
\left(\mathrm{X}_{1}\right)\end{array}$} & $\mathrm{X}_{1.1}$ & 0,633 & \multirow{7}{*}{0,3610} \\
\hline & $\mathrm{X}_{1.2}$ & 0,585 & \\
\hline & $\mathrm{X}_{1.3}$ & 0,803 & \\
\hline & $\mathrm{X}_{1.4}$ & 0,807 & \\
\hline & $\mathrm{X}_{1.5}$ & 0,531 & \\
\hline & $\mathrm{X}_{1.6}$ & 0,692 & \\
\hline & $\mathrm{X}_{1.7}$ & 0,785 & \\
\hline \multirow{15}{*}{$\begin{array}{c}\text { Reality } \\
\text { Competence } \\
\left(\mathrm{X}_{2}\right)\end{array}$} & $\mathrm{X}_{2.1}$ & 0,737 & \multirow{15}{*}{0,3610} \\
\hline & $\mathrm{X}_{2.2}$ & 0,393 & \\
\hline & $\mathrm{X}_{2.3}$ & 0,753 & \\
\hline & $\mathrm{X}_{2.4}$ & 0,787 & \\
\hline & $\mathrm{X}_{2.5}$ & 0,588 & \\
\hline & $\mathrm{X}_{3.2}$ & 0,781 & \\
\hline & X3.3 & 0,765 & \\
\hline & $\mathrm{X}_{3.4}$ & 0,530 & \\
\hline & $\mathrm{X}_{3.5}$ & 0,634 & \\
\hline & $\mathrm{X}_{3.6}$ & 0,655 & \\
\hline & $\mathrm{X}_{3.7}$ & 0,775 & \\
\hline & $\mathrm{X}_{3.8}$ & 0,501 & \\
\hline & X3.9 & 0,643 & \\
\hline & $\mathrm{X} 3.10$ & 0,808 & \\
\hline & $\mathrm{X}_{3.11}$ & 0,740 & \\
\hline \multirow{8}{*}{$\begin{array}{l}\text { Performance } \\
\text { (Y) }\end{array}$} & $\mathrm{Y}_{.1}$ & 0,668 & \multirow{8}{*}{0,3610} \\
\hline & $Y_{.2}$ & 0,768 & \\
\hline & Y.3 & 0,558 & \\
\hline & $\mathrm{Y} .4$ & 0,855 & \\
\hline & Y.5 & 0,789 & \\
\hline & $\mathrm{Y}_{.6}$ & 0,854 & \\
\hline & Y.7 & 0,798 & \\
\hline & Y.8 & 0,758 & \\
\hline
\end{tabular}

Source: Primary Data Processed, 2019

\section{b. Reliability Test}

According to Nunnally (1994) in Ghozali (2011:

47) a reliability test in this study using Cronbach Alpha coefficient formula. An instrument is said to be reliable if someone answers to the question are consistent over time. A variable constructs said to be reliable if the value Conbach's Alpha> 0.70.

Based on the results of the reliability test, that all of the variables produces Cronbach's Alpha values> 0.7 and Cronbach's Alpha If Deleted Items $>0.7$ so that it can be concluded that the statement used in testing the reliability of data on potential competence variable (X1), the competence of reality (X2), performance $(\mathrm{Y})$ are all reliable, meaning that the questionnaire used in the study were able to give consistent results when used repeatedly over time with the similarity of answers among respondents involved in filling out the questionnaire. 
Table 2

Reliability Test Result

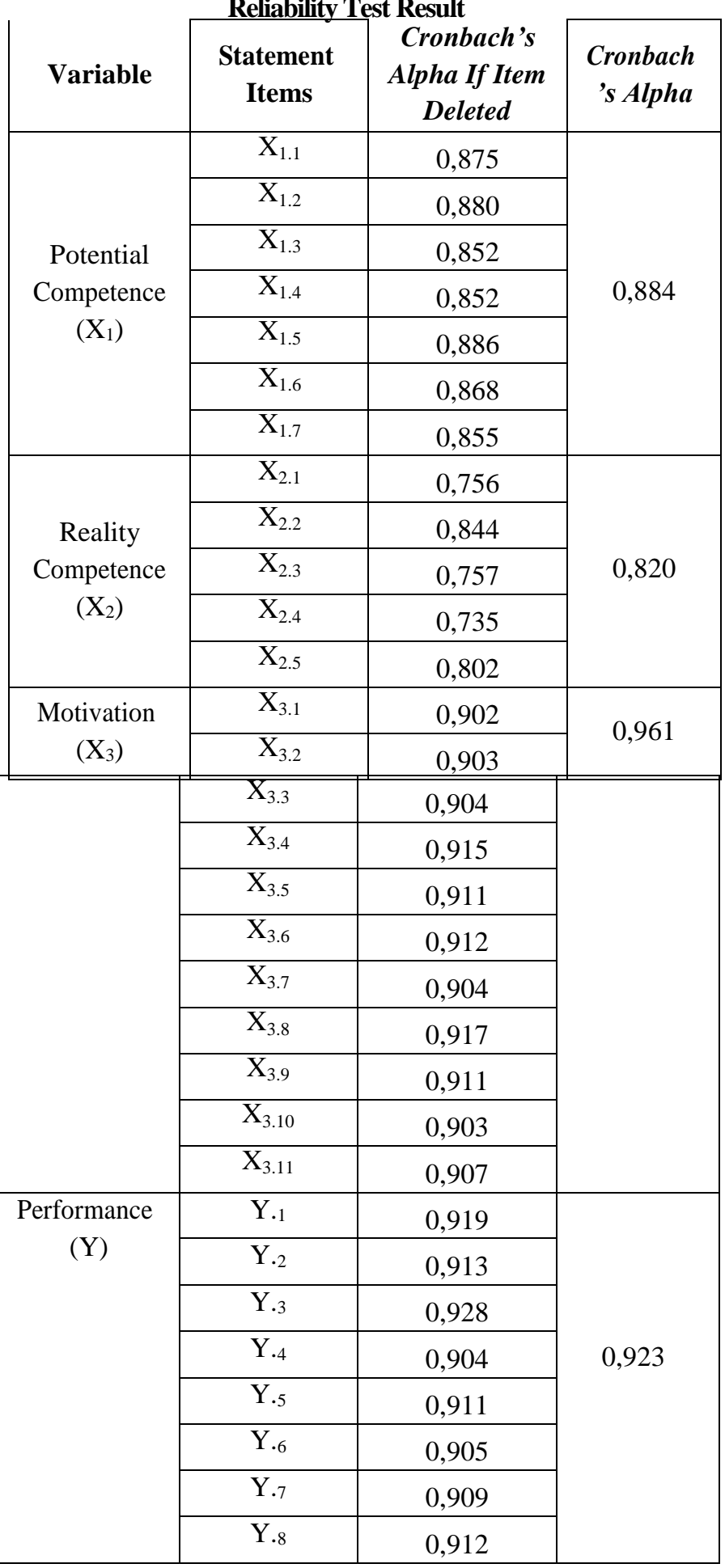


Source: Primary Data Processed, 2019

\section{RESULTS AND DISCUSSION}

\section{Research Results}

\section{a. Results of Multiple Linear Regression Analysis}

\section{Table 3}

Multiple Linear Regression Test Results

\begin{tabular}{|c|c|c|c|}
\hline Variable & $\begin{array}{c}\text { Standardized } \\
\text { Coefficients } \\
\text { Beta }\end{array}$ & $\begin{array}{c}\text { p-value } \\
\text { (sig) }\end{array}$ & Description \\
\hline $\begin{array}{c}\text { Potential } \\
\text { Competence } \\
\left(\mathrm{X}_{1}\right)\end{array}$ & 0,115 & 0,300 & $\begin{array}{c}\text { Positive, Not } \\
\text { Significant. }\end{array}$ \\
\hline $\begin{array}{c}\text { Reality } \\
\text { Competence } \\
\left(\mathrm{X}_{2}\right)\end{array}$ & 0,267 & 0,019 & $\begin{array}{c}\text { Positive, } \\
\text { Significant }\end{array}$ \\
\hline
\end{tabular}

Source: Primary Data Processed, 2019

Based on Table 1, the following equation is obtained:

$$
\mathrm{Y}=0.115 \mathrm{X} 1+0.267 \mathrm{X} 2
$$

With the following interpretation:

1) $b=0.115$. This means that the potential competence (X1) has a positive effect on performance. This shows that the higher the level of potential competence, the higher the level of employee performance.

2) $b=0.267$. This means that reality competence $(X 2)$ has a positive effect on performance. This shows that the higher the reality competency, the higher the employee's performance level.

Based on Table 1, can be described as follows:

1) The effect of potential competence (X1) on performance $(\mathrm{Y})$

To determine the effect of the independent variables, namely potential competence and reality competence on the dependent variable partially good performance, then multiple linear regression analysis was used with SPSS tools. The results of the multiple linear regression test can be seen in the following table.

\section{Potential competence regression coefficient (X1) of}

0.115 with a significance of 0.300 (> 0.05). Means H1 rejected. Thus, it is evident that the potential competence does not affect the performance of employees.

2) The influence of reality competence (X2) on performance $(\mathrm{Y})$

Reality competency regression coefficient (X2) is

0.267 with a significance of $0.019(<0.05)$. Mean H2 is accepted. Thus, reality competence has a positive effect on employee performance.

\section{HypotheticalDiscussion}

1. H1: Potential Competencies Have a Positive Effect on Performance Employees
Based on Table 7, it is known that the first hypothesis of potential competence does not affect the performance of $b=0.115(p=0,300)$ is denied. Positive regression coefficient values indicate that the high potential competence to raise the level of performance. When employees get an award in their work, the employee will feel high potential competence in the end, the performance will increase. The higher the potential competence suffered because employees have the ability to build empathy, as well as the initiative in orientation to the customer in establishing a working relationship that upholds the values of hospitality and courtesy. Principled and proactive initiatives to achieve employment targets by working with care, quality and confidence in the work. Improve achievement can be done by growing passion in digging up information as a medium of learning, the higher the level of employee performance. The results are consistent with the theory of Spencer and Spencer (1993: 9) attitude (attitude), upholding the ethics of the organization, and have a positive attitude in the act. This attitude cannot be separated from the employee's job in carrying out the job properly which is an important element that affects the image of the organization. Receipt of the first hypothesis in this study is consistent with the results of previous studies conducted by Jonnius (2015), proving that the potential competence does not affect employee performance achievement villageowned enterprises.

2. H2: Reality Competence Have a Positive Effect on Employee Performance

Based on Table 7 , it is known that the second hypothesis, namely reality competence, has a positive and significant effect on performance of $b$

$=0.267(\mathrm{p}=0.019)$ is accepted. This represents an increase of competence reality can improve performance. The higher the reality competence to employees, the higher the employee's performance. From the results of the analysis, it can be seen that, if the reality competence related to knowledge, willingness, and technical expertise are in accordance with the field of work, both in the form of work experience and talent, then the reality competence will increase. Employees are able to identify problems and find solutions to problems faced at work, so that problems will be resolved. Therefore, the higher the reality competence of employees, the higher the level of employee performance. The results are consistent with the theory of Spencer and Spencer (1993: 9) competence reality, including the ability to knowledge and skills is the ability to do a job with skill. The level of knowledge (knowledge level) contains the ability to recognize and remember the terminology, definitions, facts, ideas, patterns, sequences, methodologies, basic principles, and so on. The receipt of the second hypothesis in this study is consistent with the results of previous studies conducted by Jonnius (2015), Swandari (2017), Ataunur and Ariyanto (2015) and Musafir (2007) proved that the ability to be a decisive factor in achieving performance.

\section{CONCLUSION}

Based on the results of research and discussion on employee performance improvement strategies villageowned enterprises to use concepts potential competence and reality competence in Kulon Progo, it can be concluded as 


\section{follows:}

1. Potential competence do not affect the performance of employees of Village-Owned Enterprises in Kulon Progo Regency.

2. Reality competence has a positive effect on the performance of employees of Village-Owned Enterprises in Kulon Progo Regency.

\section{REFERENCES}

1. Ataunur, Ilmam and Eny Ariyanto. 2015. The Effect of Competence and Training on Employee Performance of PT Adaro Energy TBK. Business Review. 2 (16): 135-149.

2. Center, Media. 2019. 10 Institutions Enliven U-40 Cup Building. Downloaded from www.Kulonprogokab.go.id accessed on 17 July 2019.

3. Edison, Emron., Yohny Anwar and Imas Komariyah. 2018. Human
Resource Management. Bandung: Alfabeta.

4. Ghozali, Imam. 2011. Multivariate Analysis Application with SPSS Program. Semarang: Diponegoro University Publishing Agency.

5. Jonnius. 2014. Performance Analysis of Bumdes Employees in Kampar District. Journal of Religious Social Research. 17 (1): 84103.

6. Mangkunegara, Anwar Prabu. 2007. The HR Performance Evaluation. Bandung: Refika Aditama. Traveler. 2007. Effect of ability and motivation on employee performance Gorontalo provincial government. Ichsan Gorontalo Journal. 2 (3): 1104-

7. 1118 .

8. Spencer, Lyle M. and Signe M. Spencer. 1993. Compatence At Work. John Wiley: Sons Inc.

9. Swandari, Ni Komang Ayu Sri. 2017. Analysis of Determinants of Performance of Bumdes Employees in Jembrana Regency. E-Journal of Economics and Business, Udayana University. 6(4): 1365-1394.

10. Wibowo. 2017. Performance Management. Depok: PT Raja Grafindo Persada. 